\title{
Mandelian Rhetoric: An Analysis of Nelson Mandela's Political Speeches
}

\author{
Amitabh Vikram Dwivedi \\ School of Languages \& Literature, Shri Mata Vaishno Devi University ,Katra, Jammu (J\&K), India
}

Copyright $(2015$ Horizon Research Publishing All rights reserved.

\begin{abstract}
The paper presents an analysis of Nelson Mandela's political speeches in relation to the linguistic devices used in his political rhetoric, such as metaphor, analogies, repetition, and three-fact lists and contrastive pairs. The main goal of this study is to address how effectively this African leader employed these devices in the linguistic persuasion. The theoretical perspective of this study has been drawn from the major researches conducted on political rhetoric, including Beard; Charteris-Black; and Gibbs. The methodology follows discourse analysis of speeches delivered by Mandela on various occasions, supported by the general principles of qualitative research. This analysis becomes important as a few researches on Madiba have often criticized him for his militant speech being formulaic and rhetorically cautious and commenting that he is a politician, and not an intellectual. This study also throws some light on how speeches are generally delivered to convince and influence your audiences.
\end{abstract}

Keywords Linguistic Persuasion, Speeches, Discourse Analysis, Rhetoric.

\section{Introduction}

Every political speech becomes lively and interesting when the speaker employs linguistic devices to draw the attention of the audience. Charteris-Black states that "within all types of political system, from autocratic, through oligarchic to democratic, leaders have relied on the spoken word to convince others of the benefits that arise from their leadership" [1]. This study aims at analyzing the linguistic feature of Mandela's speeches. Keeping the analysis of the rhetoric in the forefront, the present paper intends to focus on linguistic aspects of political rhetoric, particularly their use in English language, by Nelson Mandela. In order to distinctively points out the characteristics of his kind of English language, this paper investigates and finds out linguistic features, such as allusions, metaphors, analogy, repetition, three-fact lists and contrastive pairs.

Speeches communicate with audience, and its role is to persuade and influence the people. Primarily, any good speech defines issues and problems, reconstructs the thinking, and establishes a platform for the prospective change in the society. Secondly, a speaker shows his/her personality, knowledge, charisma, and intellect while delivering the speech. To an extent this paper is expected to focus on the later function, and tries to provide a contribution to the application of Mandela's speech in rhetoric studies.

However, the readers may find that the technical and linguistic aspects are overshadowing the beauty of his language in political speeches. But overall the investigation will highlight the positive aspects of Mandela's rhetoric which help raise the voice of millions of Africans to be heard.

Like any other speeches, his speeches were also backed up with an ideology. Mandela was influenced by Marxism, and he advocated scientific socialism, and his ideological position can be understood, considering his opposition to privatization, capitalism, and land-ownership.

\section{Theoretical Background}

Many branches of linguistics such as descriptive linguistics, sociolinguistics, systemic linguistics, and the ethnography of communication provide analytic tools for analyzing speeches and the ideologies behind them. Lecocq investigated many speeches, including Reagan, Nixon, and Roosevelt. He studied the function of metaphor in political discourse [2]. Researchers, including Wenzlawski, did their studies on war speeches and the pragmatic rhetoric of war speeches [3].

Furthermore, in India, there are many works on the political speeches of Indian leaders and freedom fighters but they generally concerned with the political ideologies and social issues. The present study follows the idea that a political speech is not necessarily a success because it is composed of and based on the principles of truth and correctness; rather it may be a matter of presenting valid arguments. Charteris-Black argues that successful speakers, especially in political contexts, need to appeal to attitudes and emotions that are already within the listeners [4]. 


\section{Research Design and Samples}

This study employs qualitative methods to analyze and classify data in order to find out the distinctive linguistic features of Nelson Mandela's speeches. Furthermore, methods of descriptive linguistics are used to provide an elaborate description of some linguistic features of his speeches.

The data for this study were downloaded from various websites on the Internet. I selected ten speeches in the present work from Google search with techniques of browsing, searching, selecting, downloading, and coping.

\section{Data Analysis and Research Objectives}

The data for this paper is investigated with selecting and collecting sentences or phrases containing linguistic features. The method which was used in the study was mainly the qualitative approach. The procedure for the study is:

(1) Selecting, collecting and classifying data:read, select and collect speeches by Mandela

(2) Sorting out the data: classify and take notes of the data by linguistic functions, such as Analogy, Metaphor, Repetition, and Rhetorical Questions; and

(3) Analyzing data:point out the linguistic and stylistic features of his speeches.

The paper tries to seek two important research questions to fulfill these objectives:

(a) What are the linguistic features of Mandela's speeches in English?

(b) How does he use language to make the audience assent?

The method of analysis was to find out linguistic expressions, such as words, sentences or paragraphs where he employed as if these choices had been suggested to depict concepts and ideas in certain ways. Each selected text from the speech was analyzed separately.

\section{Findings and Discussion}

\section{Metaphors Used in Mandela'S Speeches}

Since the conceptual system of human beings is metaphorical, metaphors are often used to provide concrete labels to abstract ideas. The user of the language finds a perceived similarity between objects and concepts, and thus employs them together. Lakoff and Johnson believe that they are not only linguistic instruments but they permeate thought, perception, and behavior [5].

During a press statement issued while underground in South Africa on 26 June 1961, Mandela says:

"The struggle is my life. I will continue fighting for freedom until the end of my days." [6]
This strong metaphor might make think some critics on Mandela to consider it an example of "militant speech" being "formulaic and rhetorically cautious," and to make easy judgments that "he is a politician... ... ....and not an intellectual [7]. But the fact remains that his weaponless struggle and fight was against injustice, exploitation, poverty, and starvation for which the white government was responsible. He thinks that it is only through political freedom these various forms of segregations will come to an end. Moreover, he states his future plan of action. He staunchly believes that "Only through hardship, sacrifice and militant action can freedom be won."[8]

On his release from prison at Cape Town in South Africa on 11 February 1990, he says:

"The sight of freedom looming on the horizon should encourage us to redouble our efforts. It is only through disciplined mass action that our victory can be assured. We call on our white compatriots to join us in the shaping of a new South Africa. The freedom movement is a political home for you too." [9]

Though Mandela was unjustly sent by white government to prison where he served 27 years yet his fight was not against the white people. He had been fighting for freedom, justice and racial discrimination against black. On his release from the prison he addressed both black and white to join a disciplined mass action for "shaping of a new South Africa." He believes that both white and black will together build an apartheid-free country.

His release from the prison was not a sign of freedom for the country. In fact, he does not consider it as a freedom at all. He calls for to redouble the efforts to establish democracy in South Africa. Though he envisages that freedom is near yet he knows that it can only be achieved through continuous efforts. Similarly, in the same speech, he says:

"Our march to freedom is irreversible. We must not allow fear to stand in our way." [10]

There is no substitute to freedom. A pervasive metaphor "march" defines his role as a freedom fighter, and he includes all the countrymen it this struggle. He also mentions a vague metaphor "fear" which includes all kinds of inhibitions, including all WH-questions and ifs depicting the unpredictability of the future time.

During an address to the United Nations General Assembly at New York in USA on 3 October 1994, he says:

"In all we do, we have to ensure the healing of the wounds inflicted on all our people across the great dividing line imposed on our society by centuries of colonialism and apartheid. We must ensure that colour, race and gender become only a God-given gift to each one of us and not an indelible mark or attribute that accords a special status to any." [11]

This passage has important implications for how Mandela perceives his victory against apartheid and suppression (as this speech was delivered after 4 months of his presidency). 
Structurally, he employs two metaphorical expressions to recount the diversity of his country, namely "God-given gift" and "an indelible mark." With an active reference to the past injustice, he hopes that racial discrimination will be end from this world forever provided all the nations will stand against apartheid and colonialism.

Similarly, in Rajiv Gandhi Foundation Lecture at New Delhi in India on 25 January 1995, he says:

"If we are able today to speak proudly of a rainbow nation, united in its diversity of culture, religion, race, language and ethnicity, it is in part because the world set us a moral example which we dared to follow." [12]

Mandela compares unity in diversity of India with a rainbow where many people reside in a democratic set up, and he takes it a moral example to follow for a younger democracy of South Africa. But he enumerates that any such nation with diversity should ensure reconstruction and development for the people then a goal for a better life can be achieved.

Disregarding the political agenda of Mandela, we find in many of his metaphors he communicates at an emotional level through his speeches, and takes standpoints that seem morally correct in his situation. However, the study claims that no speech can connect to an audience solely by lexical means, although it an important factor yet the issues addressed to the listeners must be relevant to the context.

\section{Analogies Used in Mandela's Speeches}

Analogies compare two situations-contemporary with the mythical or historical. Beard states that concepts and ideas get their proper meaning when the speaker compares the present situation with the well-known phenomena. [13] These myths and historical events support the arguments of the speaker. Mandela was a champion of analogies.

During a press statement issued while underground in South Africa on 26 June 1961, Mandela says:

"Any serious politician will realize that under present-day conditions in this country, to seek for cheap martyrdom by handing myself to the police is naive and criminal." [14]

Mandela justifies his act of hiding underground, and decides not to surrender himself to the repression of the government. He does not compare himself with any specific personality or act but he makes a generalization, had in this situation any other serious politician fighting for freedom would have done the same. He further emphasizes that to surrender without fighting against the unjust would be "naïve and criminal."

During the court statement at Pretoria in South Africa between 15 October and 7 November 1962 he says:

"I hate the practice of race discrimination, and in my hatred I am sustained by the fact that the overwhelming majority of mankind hates it equally." [15]
Palmer says that discrimination means being rude and cruel to someone because he or she is different [16]. Individuals have likes and dislikes, and when one's likes and dislikes are guided by the preferences of race then it is known as race discrimination. South Africa's system of apartheid was the purest form of racial discrimination. The fact remains that a small white community was against the majority of blacks in their own country, and using various discriminatory measures of repression and suppression. Mandela stood his voice against this unjust system and he was consequently sentenced to life imprisonment. In his speech he made an analogy and included "the overwhelming majority of mankind" to support his argument.

On his release from prison, Cape Town, South Africa on 11 February 1990, he says:

"It is only through disciplined mass action that our victory can be assured. We call on our white compatriots to join us in the shaping of a new South Africa."[17]

Mandela was not only a leader of the South African people but of the world. He joined both the whites and blacks in his movement against racial discrimination. The struggles for independence around world across nations recount that it only through a disciplined mass action the foreign oppressor was forced to leave the nation. He takes help of this historical fact to emphasize and support his argument.

\section{Repetition, Three-Part Lists, and Contrastive Pairs}

Repetition is another important feature of Mandela's speech. Jones and Wareing argue that "repeating certain phrases contribute towards making the ideas contained in them seem 'common sense." [18] During a press statement issued while underground in South Africa on 26 June 1961, Mandela says:

"Those who are voteless cannot be expected to continue paying taxes to a government which is not responsible to them. People who live in poverty and starvation cannot be expected to pay exorbitant house rents to the government and local authorities." [19]

Similarly, during the court statement at Pretoria in South Africa between 15 October and 7 November 1962 he uses three-pair lists:

"I hate the practice of race discrimination, and in my hatred I am sustained by the fact that the overwhelming majority of mankind hates it equally. I hate the systematic inculcation of children with colour prejudice and I am sustained in that hatred by the fact that the overwhelming majority of mankind, here and abroad, are with me in that. I hate the racial arrogance which decrees that the good things of life shall be retained as the exclusive right of a minority of the population, and which reduces the majority of the population to a position of subservience and inferiority, and maintains them as vote less chattels to work where they are told and behave as they are told 
by the ruling minority. I am sustained in that hatred by the fact that the overwhelming majority of mankind both in this country and abroad are with me." [20]

Mandela also uses contrastive pairs in his speeches, such as during a press statement issued while underground in South Africa on 26 June 1961, Mandela uses contrastive pairs:

"Will you come along with us, or are you going to cooperate with the government in its efforts to suppress the claims and aspirations of your own people?" [21]

And a sort of three-part lists is used in his address to the United Nations Special Committee Against Apartheid at New York in UNS on 22 June 1990; where he says:

"Let us travel it together. Let us, by our joint actions , vindicate the purposes for which this Organization was established and create a situation where in its Charter and the Universal Declaration of Human Rights will become part of the body of law on which will be based the political and social order of a new South Africa. Our common victory is assured." [22]

In long speeches words and phrases repetition is employed to hold the speech together, and to help draw listeners' attention to the arguments. Three-part lists are a modified form of repetition where the speaker introduces new ideas in a sequence. The first part introduces the arguments, and the last two complements and closes it. Mandela does not strictly follow the three-part lists but he modifies it according to the context.

\section{Conclusions}

Linguistic analysis relates the linguistic behavior to political behavior. At micro-level, we can seek which strategic functions, language structures serve, or at macro-level we can seek which linguistic structures, the function of the text fulfills. The use of metaphors, contrastive pairs, repetitive words and phrases are variations of the literary and ordinary speech. But this usage makes the argument more effective and striking. The purpose of most of the Mandela's speeches was not to provide news and information to the public as mostly presidents and prime ministers of various nations do, but to motivate the people for an ongoing struggle against poverty, discrimination, segregation, and injustice.

His usage of metaphors, analogies, repetition, and contrastive pairs might not be fresh or new but his speeches would become successful to create mental images in the minds of his fellow countrymen against oppression and suppression. For that reason, whenever we remember him we remember him as a global citizen who had a firm belief in freedom, justice, and human equality.

The qualitative method suggests that metaphors and repetition are the most frequently employed linguistic devices in his speeches. Metaphors are twice frequent than repetition in ten speeches. Metaphors, ranging from signaling discrimination to motivate the fellow-countrymen, generally employed to include their emotions against racial discrimination. Three-pair lists occur least in the speeches; moreover their pattern does not follow the three-stages.

\section{REFERENCES}

[1] Charteris-Black, J., 2005, Politics and Rhetoric: The Persuasive Power of Metaphor. Houndmills, Basingstoke, Hampshire, New York: Palgrave Macmillan.

[2] Lecocq, C., 1985, An Investigation of Several Speeches by Roosevelt, Nixon, and Reagan,With regard to the Function of Metaphor in Political Discourse. UniversiteLibre de Bruxelles (Belgium), Undergraduate Dissertation.

[3] Wenzlawski, J., 2011, Words at War - The pragmatic rhetoric of war speeches: A comparison of war speeches by Winston Churchill and George W. Bush. Munich: GRIN Verlag GmbH.

[4] Charteris-Black 2005, Op. cit.

[5] Lakoff, G. and M. Johnson, 1980, Metaphors We Live By. Chicago: The University of Chicago Press.

[6] Mandela, N., Asmal, K., Chidester, D., \& James, W., 2003, In his own words. New York, N.Y: Little, Brown and Co.

[7] Boehmer, E. Nelson, 2008,Mandela: A Very Short Introduction. Oxford: Oxford University Press.

[8] Mandela, N., Asmal, K., Chidester, D., \& James, W. G., 2003, In his own words. New York, N.Y: Little, Brown and Co.

[9] Ibid., p. 14

[10] Ibid., p. 14

[11] Ibid., p. 19

[12] Ibid., p. 22

[13] Beard, A., 2000, The Language of Politics. London: Routledge.

[14] Mandela, N., Asmal, K., Chidester, D., \& James, W. G., 2003, In his own words. New York, N.Y: Little, Brown and Co.

[15] Ibid., p. 10

[16] Palmer, Ezra., 1995,Everything You Need to Know About Discrimination. New York: Rosen Pub. Group.

[17] Ibid., p. 22

[18] Jones, J. and S. Wareing, 1999, Language and Politics. In Thomas, L. et.al (eds), Language, Society, and Power. London: Routledge. pp. 31-47.

[19] Mandela et. al. 2003, op. cit. p. 8

[20] Mandela et. al. 2003, op. cit. p. 10

[21] Mandela et. al. 2003, op. cit. p. 8

[22] Mandela et. al. 2003, op. cit. p. 18 